\title{
Early growth of a pioneer recruited coral Oulastrea crispata (Scleractinia, Faviidae) on PFA-concrete blocks in a marine park in Hong Kong, China
}

\author{
Katherine K. Y. Lam* \\ The Swire Institute of Marine Science and Department of Ecology and Biodiversity, The University of Hong Kong, \\ Cape d'Aguilar, Shek O, Hong Kong, China
}

\begin{abstract}
In December 1993, an experimental artificial reef made of pulverised fuel ash (PFA) and concrete was deployed at Hoi Ha Wan Marine Park, Hong Kong. Oulastrea crispata was the pioneer coral recruited on the structure. The initial growth of juveniles on the retrieved PFA-concrete blocks was analysed in an attempt to explain why and how this, and only this, scleractinian was able to colonize such a new marine habitat. Growth occurred through extra- and intra-tentacular budding. Juvenile growth, expressed as geometric diameter extension rate, of O. crispata was assessed by 2 methods. First, growth was estimated by the repeated measurement of the same colonies for a period of $12 \mathrm{mo}$. Mean growth rate was $1.04 \pm 0.05 \mathrm{~mm} \mathrm{mo}^{-1}(\mathrm{n}=105)$. Second, growth was estimated from the size of new recruits at an age of 3 mo on the PFA-concrete blocks. Mean growth rate was $0.9 \pm 0.51 \mathrm{~mm} \mathrm{mo}^{-1}(\mathrm{n}=10)$. The first approach also showed that the growth rate of $O$. crispata was higher in winter and spring (from December to April) than summer and autumn (from April to December). With an opportunist life history trait, a wide range of reproductive strategies and surfaceorientation independent growth, O. crispata is able to colonize a variety of substrata and to flourish as a pioneer colonizer of newly immersed structures.
\end{abstract}

KEY WORDS: Coral · Oulastrea crispata $\cdot$ Growth $\cdot$ Artificial reef $\cdot$ Pulverised fuel ash

Resale or republication not permitted without written consent of the publisher

\section{INTRODUCTION}

The growth of the colony base has ecological significance to a sessile organism in terms of juvenile survival. Size refugia from predation and grazing (Miller \& Carefoot 1990, Berlow \& Navarrete 1997, Brown 1997), competition (McFadden 1986) and environmental factors (Wittenberg \& Hunte 1992, Nie et al. 1996) have been documented as important factors in the survival and growth of marine sessile communities. Corals are vulnerable to grazers after planulae settlement, particularly before the skeleton is laid down (Fitzhardinge 1993). Some authors have suggested that early maximal growth in corals, whereby minor damage no longer implies the total loss of the colony, plays an important role in reducing post-settlement mortality (Van Moorsel 1988).

*E-mail: kkyl@graduate.hku.hk
Several approaches have been applied to deduce the growth rate of juvenile corals. Growth rates can be underestimated by measuring recruits present on artificial substrata of known immersion time (Vaughan 1912, Rogers et al. 1984, Alino et al. 1985, Wallace et al. 1986), or on cleared reef substrata (Rogers et al. 1982, Hughes 1985). Actual growth rates can be obtained only if the size of the same coral is monitored over an extended period of time. Such juveniles could be laboratory-reared (Vaughan 1915, Babcock 1985, Sato 1985), present either on the natural reef (Bak \& Engel 1979, Rosesmyth 1984, Van Moorsel 1985) or on an artificial substratum (Loya 1976a, 1985, Rylaarsdam 1983, Fitzhardinge 1993). Interspecific initial growth rates are comparable as juvenile growth forms in corals are either encrusting or 2-dimensional, regardless of the various adult morphologies (Van Moorsel 1988). Studies of maximum extension rates in coral juveniles also reflect the minimum time required between settlement and discovery (Van Moorsel 1988, 1989). 
Using coal ash or pulverised fuel ash (PFA) for artificial reefs is an option for waste disposal, but is still controversial as such residues contain trace metals of environmental concern, for example, $\mathrm{Al}, \mathrm{As}, \mathrm{Cd}, \mathrm{Cu}, \mathrm{Cr}, \mathrm{Fe}$, $\mathrm{Pb}$, Se and $\mathrm{Zn}$. One of the ways to determine the compatibility of ash-concrete material with the marine environment, particularly as to whether or not it is harmless to marine organisms, is to study the attaching organisms which are in physical contact with this material. Bamber $(1984,1990)$ suggested that fly ash itself is not toxic to marine invertebrates. The results of past epifaunal colonization studies on various ash reefs in temperate waters have produced results which suggest PFA-concrete is similar to concrete as a marine substratum (Duedall et al. 1981, Humphries et al. 1985, Woodhead \& Jacobson 1985a,b, Woodhead et al. 1985, Nelson et al. 1988, Savercool 1988, Neth 1991). There are also studies which have shown that ash blocks supported a higher diversity of organisms (Flynn et al. 1985, Sampaolo \& Relini 1993). There is, however, little information on growth of the invertebrates on such ash reefs. If artificial ash reefs were constructed for coral reef restoration, the effect of such a substratum on coral growth, if any, has to be assessed for its suitability for such a purpose.

Throughout the 2 yr study on the epibiotic colonization of the experimental artificial PFA-concrete reef at Hoi Ha Wan, Hong Kong, Oulastrea crispata (Scleractinia, Faviidae) was the only coral to show significant recruitment (Lam 1998). In this study, the juvenile growth of $O$. crispata was examined. The objectives of this study were 2-fold: (1) to identify the seasonal growth patterns of juvenile $O$. crispata, and (2) to assess the differences, if any, in growth onto concrete blocks with a gradient of PFA compositions and with respect to surface orientation.

\section{MATERIALS AND METHODS}

Study site and sampling. The artificial reef was deployed on an area of sea bed at -7 m Chart Datum within Hoi Ha Wan (Fig. 1). The sea bed of the study area had been smothered by the runoff of silt from surrounding hills, which were used as a land borrow area between 1981 and 1989. Despite reforestation of the hills, the sea bed of the study area was still covered by at least $0.5 \mathrm{~m}$ of loose mud on top of a hard substratum, where there had been a coral community (Zou et al. 1992).

The artificial reef comprised 1000 cuboidal structural blocks $500 \mathrm{~mm}$ in length, with a hollow central cylinder of $200 \mathrm{~mm}$ diameter, to increase their surface areas as well as provide shelter for resident fish and invertebrates. The blocks were deployed in a random fashion from a barge within the gazetted site from 1 to 3 December 1993. The shape of the artificial reef was somewhat like a pyramid with a base area of approximately $10 \times 10 \mathrm{~m}$ and a height of $2.5 \mathrm{~m}$ (Fig. 2). During the deployment of the artificial reef in December 1993, a set of test blocks $15 \times 15 \times 15 \mathrm{~cm}$, including 90 each of the 4 PFA-concrete mixes, were placed on top of the artificial reef. Both the structural and test blocks were made of different concrete to PFA compositions, as shown in Table 1. The formulation of these blocks was based on a cement replacement by PFA concept (Leung et al. 1995, 1997). In another study, epifaunal community de-

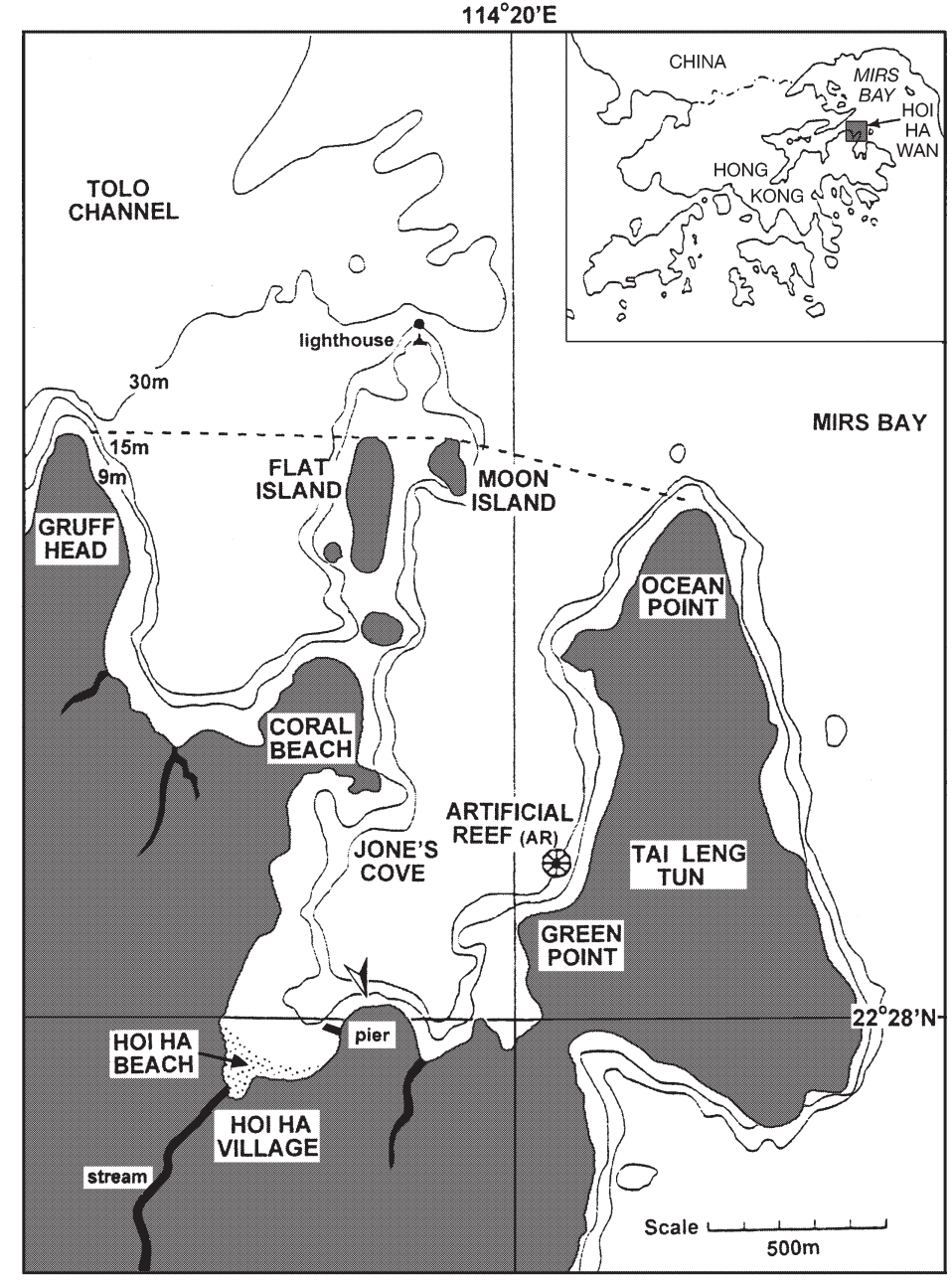

Fig. 1. Map of Hoi Ha Wan, Hong Kong, showing the locations of the artificial reef (AR) (depth contours in $\mathrm{m}$ ) 
velopment was followed for the next $2 \mathrm{yr}$ by examining the test blocks after 3, 6, 9, 12, 15, 18, 21 and 24 mo, i.e. in March 1994, June 1994, September 1994, December 1994, February 1995, June 1995, September 1995 and December 1995, respectively (Lam 1998). A total of 16 test blocks were retrieved each time, with no replacement, as there were 4 test blocks of each mix and 4 replicates. Oulastrea crispata recruited on the test blocks retrieved in September 1994 and onwards. Test blocks retrieved in September 1994 and December 1995 were used only to study O. crispata growth.

Upon retrieval, the test blocks were transported in seawater to the Swire Institute of Marine Science and kept in open-air tanks supplied with fresh, sedimentfree, running seawater. They were shielded during times of strong sunlight and rainfall, and the tanks were sufficiently oxygenated. They were kept in the same orientation as they had been in on the artificial reef. Four faces of the blocks were examined and each was divided into 4 categories as follows: (1) the sheltered surface, i.e. the side of the test block which had the most contact with the main reef modules; (2) the vertical or inclined surface which was exposed to the open sea; (3) the top surface, which was more or less horizontal to the water surface; and (4) the base of the test block.

Juvenile growth. Juvenile growth rates, expressed as monthly linear extension rates of the coral's geometric diameter $\left(\mathrm{mm} \mathrm{mo}^{-1}\right)$, were determined using 2 methods: (1) measuring the same coral repeatedly and (2) deducing them from sizes of Oulastrea crispata colonies growing on blocks of known immersion time.

For the first approach, Oulastrea crispata recruits on 16 test blocks retrieved in December 1995 were studied. A total of 16 test blocks were retrieved, as there were 4 test blocks of each mix and 4 replicates. The



Fig. 2. An impression of the experimental artificial reef at Hoi Ha Wan
Table 1. Composition in terms of dry weight of the different types of blocks deployed on the artificial reef. PFA: pulverised fuel ash

\begin{tabular}{|c|c|c|c|c|c|}
\hline \multirow[t]{2}{*}{ Block type } & \multicolumn{4}{|c|}{ Test block } & \multirow{2}{*}{$\begin{array}{c}\text { Structural } \\
\text { block }\end{array}$} \\
\hline & $\mathrm{A}$ & B & $\mathrm{C}$ & $\mathrm{D}$ & \\
\hline PFA: cement by volume & $0: 1$ & $1: 3$ & $1: 1$ & $3: 1$ & $1: 1$ \\
\hline PFA $(\%)$ & 0 & 3.2 & 6.6 & 9.7 & 6.6 \\
\hline Portland cement (\%) & 13.1 & 9.7 & 6.6 & 3.2 & 6.6 \\
\hline $20 \mathrm{~mm}$ aggregate $(\%)$ & 41.8 & 41.9 & 41.6 & 41.8 & 41.6 \\
\hline $10 \mathrm{~mm}$ aggregate $(\%)$ & 11.3 & 11.3 & 11.2 & 11.3 & 11.2 \\
\hline Fine stone $(\%)$ & 33.8 & 33.9 & 33.8 & 33.9 & 33.8 \\
\hline Water (\%) & 6.9 & 6.4 & 9.0 & 7.6 & 9.0 \\
\hline
\end{tabular}

geometric diameter of each coral colony was calculated using the following equation:

$\sqrt{\text { max. diagonal length } \times \text { length } \perp \text { to max. diagonal length }}$

Each recruited coral colony was monitored every 2 months, for a period of 12 mo (from December 1995 to December 1996). Vernier calipers with a $10^{-1} \mathrm{~mm}$ scale were used for all such measurements. Repetitive measurement of the same coral colonies gave a range of figures which varied within $0.5 \mathrm{~mm}$. The median of 3 readings was taken as the measurement on each occasion.

For the second approach, retrieved batches of test blocks initially seen to have coral recruits were studied, i.e. those retrieved in September 1994. Geometric diameters of each coral recruit were measured with the assumption of an initial size of zero. They could, however, have settled at any time within the preceding 3 mo (from June to September 1994). For both approaches, growth values were expressed as the monthly linear extension rate of the coral's geometric diameter.

Statistical analyses. Data were tested for normality using the KolmogorovSmirnov test (Zar 1984) and for homogeneity of variance using Bartlett's test (Bartlett 1937), both at the 0.05 significance level, prior to ANOVA. The growth of young individual colonies, calculated in terms of $\mathrm{mm} \mathrm{mo}^{-1}$ using the repeated measurements, were tested by 3-way ANOVA for the significance of month, block type and orientation. Student-Newman-Keuls (SNK) and Duncan multiple comparison tests were used, when the null hypothesis was rejected, to ascertain where the differences lay (Sokal \& Rohlf 1995). Pearson $(r)$ and Kendall's $(\tau)$ correla- 
tion tests were performed between colony size and annual juvenile growth rate, to detect any size-dependent growth. The growth rate data obtained from both approaches were tested using Levene's test for equality of variances, prior to testing the null hypothesis that there was no difference in growth rates by an independent samples $t$-test at the 95\% confidence interval. Data analyses were performed using Microsoft ${ }^{\circledR}$ Excel 97 (Microsoft Office 97, 1985-1996 Microsoft Corporation) and SPSS for Windows Release 7.5 (SPSS Inc. 1996).

\section{RESULTS}

\section{Quantitative juvenile growth}

Overall growth, expressed as the linear extension rate of Oulastrea crispata $(\mathrm{n}=105)$ and estimated by repeated measurement of the same colonies for a period of $12 \mathrm{mo}$, ranged from 0.6 to $1.3 \mathrm{~mm}$ with a mean of $1.04 \pm 0.05 \mathrm{~mm} \mathrm{mo}^{-1}$ and a range of 0.92 to $1.2 \mathrm{~mm} \mathrm{mo}^{-1}$. The mortality of $O$. crispata in this $12 \mathrm{mo}$ period was 3 of the 108 colonies measured. Three-way ANOVA (2-tailed at the 0.05 significance level) showed that growth rates differed significantly between months $(p=0)$, but not between block types $(p=0.3)$ and orientations $(p=0.07)$ (Table 2$)$. Both the SNK and Duncan multiple comparison tests grouped the growth rate subsets into a descending order as follows: (1) February 1996, (2) April 1996 and (3) June, August, October and December 1996. That is, growth rates were greatest between December 1995 and February 1996, at $1.14 \mathrm{~mm} \mathrm{mo}^{-1}$, with a subsequent decrease to 1.09 and $1.03 \mathrm{~mm} \mathrm{mo}^{-1}$ in April and June 1996, respectively. In August, October and December 1996, growth rates remained stable and ranged from 1.01 and $1.03 \mathrm{~mm}$ $\mathrm{mo}^{-1}$ (Fig. 3). In general, growth rates declined in the initial $4 \mathrm{mo}$ (December 1995 to April 1996) and levelled off subsequently. The growth rates of coral recruits onto different block types and at different surface orientations were the same, as shown by the single subset grouped by both the SNK and Duncan tests, in addition to ANOVA. There was no interaction among the 3 factors of month, block type and surface orientation and, thus, no effect of such variables upon coral recruit growth rates (ANOVA; $p=0.86$ ). The occurrence of any one of the factors did not, therefore, influence another in terms of growth rate. The initial sizes, in terms of geometric diameter, of the recruits used in this growth measurement approach were $6.74 \pm 2.13 \mathrm{~mm}$. There was also insignificant size-dependent growth as the Pearson $(r)$ and Kendall's $(\tau)$ correlation coefficients (both 2-tailed) between initial coral geometric diameter and annual linear extension rate were $0.07(p=0.475)$ and 0.067 $(\mathrm{p}=0.358)$, respectively.

Oulastrea crispata first recruited onto both vertical and inclined surfaces of the test blocks in September 1994. Only 10 observable recruits occurred on the 16 retrieved blocks. Some of the colonies were singlepolyped; others had budded with several smaller daughter polyps surrounding a central larger parent. The size ranged between 1 and $5 \mathrm{~mm}$, with a mean of $2.67 \pm 1.53 \mathrm{~mm}$. As these coral recruits attached onto the test blocks during the period between June and September 1994, their assumed maximum age was 3 mo. The corresponding estimated growth rates, therefore, ranged from 0.3 to $1.7 \mathrm{~mm} \mathrm{mo}^{-1}(\mathrm{n}=10)$, with a mean of $0.9 \pm 0.51 \mathrm{~mm} \mathrm{mo}^{-1}$.

Growth rates obtained by the 2 approaches, repeated measurement of the same recruits and deductions obtained from new recruits on blocks of known immersion time, were shown to be similar using an independent sample $t$-test at the $95 \%$ confidence level ( $p=0.3,2$-tailed, equality of variances not assumed as Levene's test for equality of variances failed at $p=0$ for the data sets).

Table 2. An analysis of the growth rates of coral recruits obtained by repeated measures every 2 mo for 12 mo in terms of seasons, block type and block surface orientations. Three-way ANOVA results show that $\mathrm{H}_{01}$ : between-bimonthly growth rate was the same. $\mathrm{H}_{02}$ : between-block type growth rate was the same. $\mathrm{H}_{03}$ : Between-surface orientation growth rate was the same. $\mathrm{H}_{04}$ : There was no interaction between the 3 factors: season, block type and surface orientation $\left(\mathrm{H}_{01}-\mathrm{H}_{04}=\right.$ null hypotheses 1-4). Computed using $\alpha=0.05$. ${ }^{*}$ Significant at $\mathrm{p}<0.05$. ns $=$ not significant

\begin{tabular}{|lrrrrrc|}
\hline Source of variation & SS & df & MS & $F$ & Sig. & Remarks \\
\hline Month & 1.35 & 5 & 0.27 & 27.18 & 0 & $*$ \\
Block & 0.04 & 3 & 0.01 & 1.21 & 0.30 & $\mathrm{~ns}$ \\
Orien & 0.05 & 2 & 0.03 & 2.67 & 0.07 & $\mathrm{~ns}$ \\
Month $\times$ Block & 0.16 & 15 & 0.01 & 1.08 & 0.37 & $\mathrm{~ns}$ \\
Month $\times$ Orien & 0.05 & 10 & 0.01 & 0.54 & 0.86 & $\mathrm{~ns}$ \\
Block $\times$ Orien & 0.12 & 6 & 0.02 & 1.95 & 0.07 & $\mathrm{~ns}$ \\
Month $\times$ Block $\times$ Orien & 0.22 & 30 & 0.01 & 0.72 & 0.86 & $\mathrm{~ns}$ \\
Total & 706.96 & 630 & & & & \\
Corrected total & 7.55 & 629 & & & & \\
& & & & \\
Groupings according to results from the SNK and Duncan multiple comparison \\
tests $(\alpha=0.05)$. Subsets with similar growth rates for months: February 1996 > April \\
1996 $>$ June 1996 = August 1996 = October 1996 = December 1996 \\
\hline
\end{tabular}




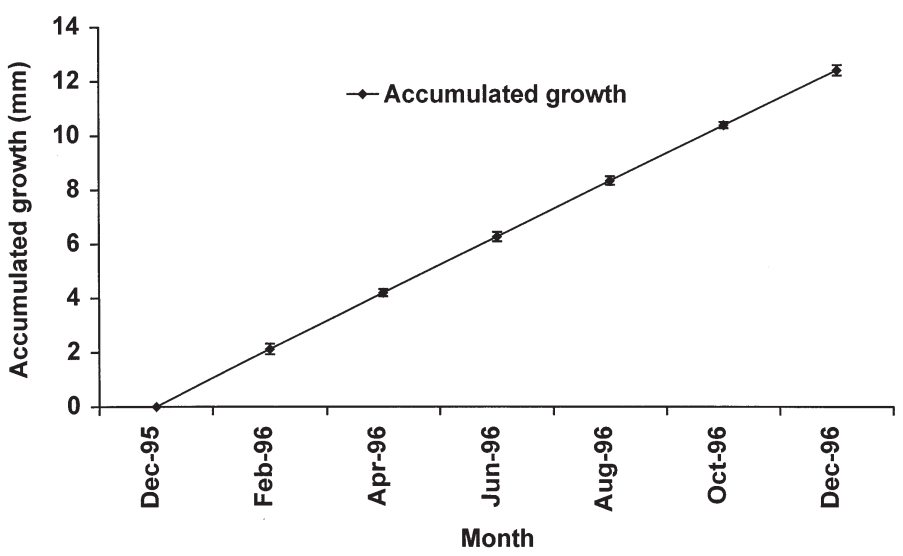

Fig. 3. Growth rate, in terms of linear extension in geometric diameter $(\mathrm{mm})$, of Oulastrea crispata recruits onto PFA-concrete blocks, measured bimonthly, from December 1995 (Month 0) to December 1996 (Month 12). Vertical bars denote standard deviations. Values for the mean of the coral recruits measured at each bimonthly interval $(n=105)$

\section{Modes of budding}

A total of 154 colonies of Oulastrea crispata were investigated for signs of extra- and intra-tentacular budding. The majority of the colonies, regardless of size, carried out extra-tentacular budding at the colo- ny peripheries (Fig. 4A). The smallest colony which showed extra-tentacular budding had a geometric diameter of $4.5 \mathrm{~mm}$. The size of fully grown polyps, i.e. the oldest polyps in the centre of a colony, ranged from 4.5 to $6 \mathrm{~mm}$. A linear relationship between colony surface area and number of polyps in a colony is shown in Fig. 5. Only 1 colony, with a geometric diameter of $31 \mathrm{~mm}$, showed intra-tentacular budding by its central polyps (Fig. 4B).

\section{DISCUSSION}

\section{Juvenile growth of Oulastrea crispata}

The published coral recruit growth rate range is between 1.4 and $2.3 \mathrm{~mm} \mathrm{mo}^{-1}$ for the Acroporidae (Acropora cervicornis, A. millepora, A. pruinosa, Acropora sp., Montipora informis and $M$. venosa), 0.8 to $2.8 \mathrm{~mm} \mathrm{mo}^{-1}$ for the Agariciidae (Agaricia agaricites, A. humilis, A. fragilis and Agaricia sp.), 0.6 to $2.4 \mathrm{~mm}$ $\mathrm{mo}^{-1}$ for the Poritidae (Porites astreoides, P. porites, P. lobata and Porites sp.), 1.3 to $1.9 \mathrm{~mm} \mathrm{mo}^{-1}$ for the Pocilloporidae (Madracis pharensis, Stylophora pistillata, Pocillopora damicornis and Pocillopora sp.), 0.4 to $1.7 \mathrm{~mm} \mathrm{mo}^{-1}$ for the Faviidae (Diploria sp., Manicinia areolata, Colpophyllia natans, Favia fragum, Cyphastrea microphthalma and Cyphastrea serailia), $1 \mathrm{~mm}$
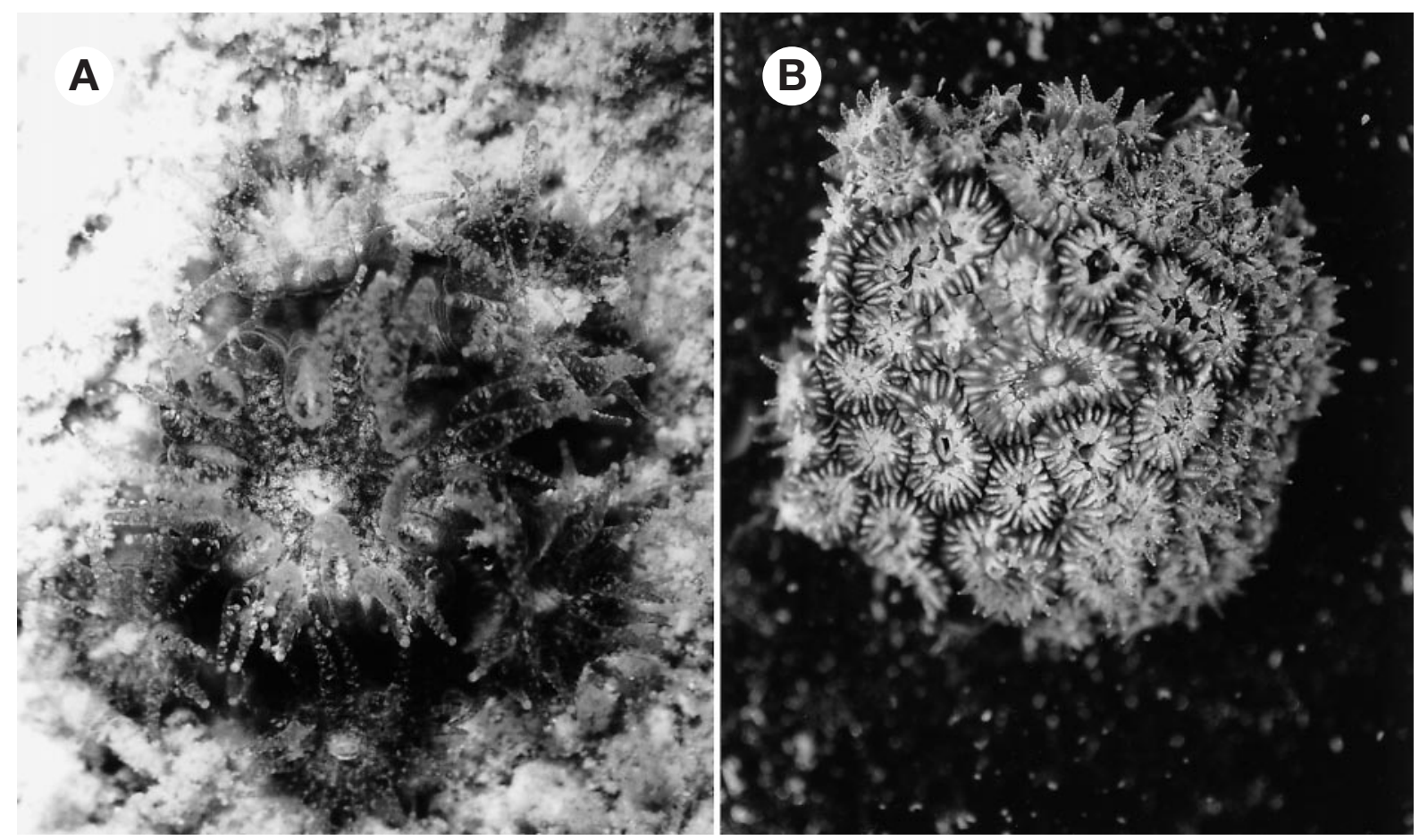

Fig. 4. Oulastrea crispata colonies. (A) O. crispata with new, smaller, buds at the periphery derived by extra-tentacular budding $(\times 8)$. (B) Intratentacular budding of central polyps of an $O$. crispata colony $(\times 2)$ 


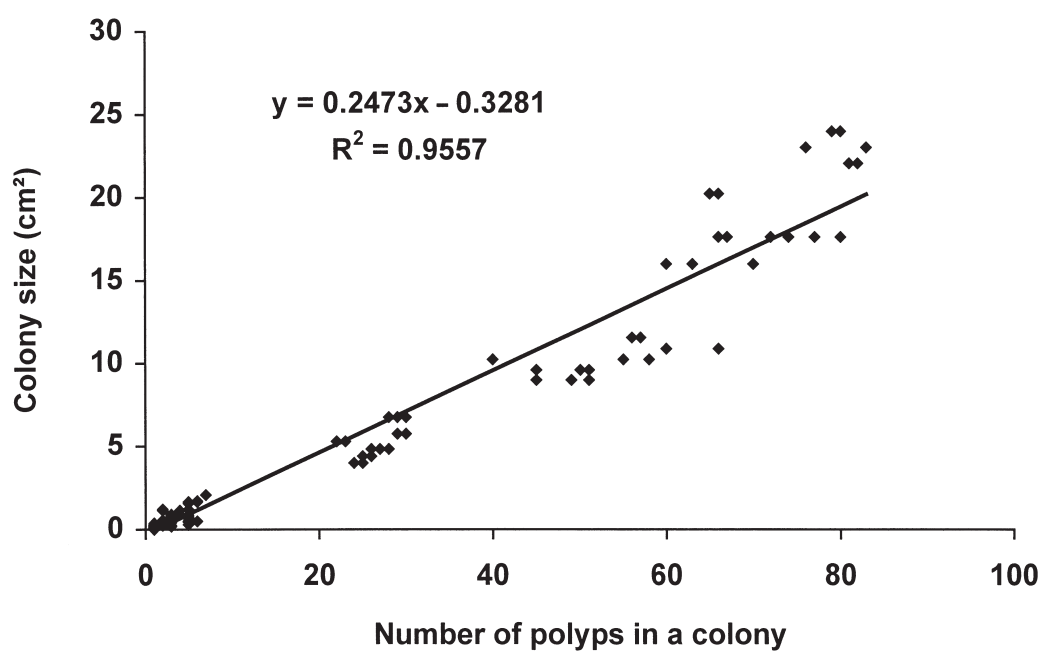

Fig. 5. Relationship between colony size (in terms of surface area) and numbers of polyps in Oulastrea crispata colonies. Colony surface areas were calculated from geometric diameters, assuming the colonies were circular in shape. Total number of colonies measured $=154$

$\mathrm{mo}^{-1}$ for the Meandrinidae (Meandrina meandrites), $1.2 \mathrm{~mm} \mathrm{mo}^{-1}$ for the Mussidae (Mycetophyllia sp.), 2.3 to $2.5 \mathrm{~mm} \mathrm{mo}^{-1}$ for the Dendrophylliidae (Tubastrea coccinea) and $>0.9 \mathrm{~mm} \mathrm{mo}^{-1}$ for the Caryophylliidae (Eusmilia fastigiata) (van Moorsel 1988).

The mean juvenile growth rate value of Oulastrea crispata obtained in this study, between 0.9 and $1.04 \mathrm{~mm} \mathrm{mo}^{-1}$, falls within the range for the Faviidae. When comparing the upper values in the above ranges, the maximum possible juvenile growth rate of representatives of the Faviidae appears to be lower than the other major families, including the Acroporidae, Agariciidae, Poritidae and Pocilloporidae. On a local scale, the juvenile growth rates of $O$. crispata were the lowest among such species as Montipora informis, $M$. venosa, Cyphastrea microphthalma, C. serailia, Porites lobata and Acropora pruinosa (Scott 1984). The relatively slow growth rate and small size of $O$. crispata has led to the suggestion that it might lose to competition from other corals (Kawaguti \& Sakumoto 1952). Competition between O. crispata and other corals was seen only twice in the field during this study, and the former lost to Favia speciosa. At the area of contact, the $O$. crispata polyps appeared bleached and retreated, while the other faviid looked healthy (author's pers. obs.). F. speciosa has been shown to be in an intermediate position in the interspecific aggression dominance hierarchy determined for Hong Kong corals (Cope 1982). Therefore, O. crispata has a low rank in the hierarchy. In Tsukumo Bay, Japan, $O$. crispata was always smothered by overgrowths of the coralline alga Lithophyllum yendoi (Yajima et al. 1986). In local coral communities, O. crispata is usually dis- tributed either on shaded boulder surfaces or on surfaces which are susceptible to sedimentation, i.e. in places where other corals are rare (author's pers. obs.). Sheppard (1979) showed that, in some instances, the order of coral aggression correlates well with the corresponding distributions. Further investigations are needed to determine whether the low competitiveness resulting from slow growth and low aggressiveness in $O$. crispata contributes to its distribution within the total coral community.

Using measures of recruit size on substrata of known immersion period, the growth rate of Oulastrea crispata was underestimated. This is because recruitment can occur at any time during the initial 3 mo immersion period, through asexual planulae and sexual recruits. The error in growth rate estimation, therefore, will increase with longer immersion times. In this study, the calculated growth rate values did not, however, differ significantly from those obtained by the repeated measurement approach. This shows that the latter is a reliable way to measure growth in new coral recruits on substrata experiencing a short immersion time, such as several months. In past studies, most authors have adopted the substratum immersion time approach to measure recruit growth rates on either artificial (Vaughan 1912, Rogers et al. 1984, Alino et al. 1985, Wallace 1985, Wallace et al. 1986) or cleared reef substrata (Rogers et al. 1982, Hughes 1985). This method is advantageous because only a single field sampling is required. Several repeated measurements of corals which have settled on artificial reef substrata are used (Loya 1976a, 1985, Rylaarsdam 1983, Van Moorsel 1988) to measure real growth rates as well.

This study showed that the linear extension rate of Oulastrea crispata is independent of juvenile diameter. Such results are consistent with previous studies. Van Moorsel (1985) showed that newly settled Agaricia humilis recruits exhibited constant linear growth, irrespective of colony size. A similar finding of constant absolute growth by Stylophora pistillata was obtained by Loya (1976b). Yamaguchi (1983) also demonstrated linear growth for the branching coral Pocillopora damicornis within the studied size range.

The growth rate of Oulastrea crispata was higher in winter and spring (December 1995 to June 1996) than summer and autumn (June to December 1996). This is somewhat surprising, as one would expect that growth from summer to winter, when water temperatures are higher, to be greater. The gradual decrease in growth rates starting in early summer could have been caused by changes in in vitro physical factors, such as water temperature. Alternatively, it may be that $O$. crispata is 
more acclimated to lower temperatures. An increase in growth from summer to winter has also been demonstrated for Porites lobata locally (Collinson 1997).

Similar Oulastrea crispata linear extension growth rate values with regard to block type have been demonstrated in this study. Substratum-related growth studies of juvenile corals are rare. Van Moorsel (1988) showed a general similarity in coral recruit linear growth rates on 2 different artificial substrata, smooth polystyrene and formica.

The growth rates of local Oulastrea crispata recruits also did not vary between different surface orientations. As the 3 different orientations, i.e. horizontal, vertical and bottom, received different light levels, this implies that illumination is not a factor controlling juvenile growth in the zooxanthellate $O$. crispata. That is, this species has a wide range of photo-adaptation, to survive in areas of maximum light, such as on the top of horizontal blocks, and the lowest, such as underneath surfaces. This also agrees with its observed natural distribution on shaded boulder surfaces. There are few studies on the relationship between surface orientation and coral juvenile growth. Van Moorsel (1988) recorded slower growth rates for zooxanthellate hermatypic juveniles on shaded surfaces than those located on the exposed surfaces of artificial structures. No conclusion was, however, drawn for the studied ahermatypic species. The effect of surface orientation on juvenile growth in corals, thus, seems to depend on the species.

This study shows that Oulastrea crispata can bud extra- and intra-tentacularly. The former mode of budding is exhibited in colonies of all ages, while the latter is seen in the central polyps of larger colonies (geometric diameter $=31 \mathrm{~mm}$ ). It seems that a polyp can carry out intra-tentacular budding only when it reaches a certain size or age. Since there was only 1 observation of intra-tentacular budding, this is obviously of minor importance to the species life history. Intra-tentacular budding is also seen in Japanese (Yajima et al. 1986) and Australian (Veron 1986) conspecifics.

In conclusion, Oulastrea crispata is well adapted with regard to its mode of reproduction and growth for survival in the perturbated shallow marine environment of Hong Kong. It is hermaphroditic and has an annual gametogenic cycle with an extended spawning period from July to October. It broods and releases planulae in the resting period of the gametogenic cycle (Lam 1998). By releasing larvae in all seasons, the chance of new colony establishment is enhanced. The ability to release planulae in small, newly recruited $O$. crispata implies that this species can colonize a new surface within a short time. It can, moreover, carry out both extra- and intra-tentacular budding to increase the number of polyps in a colony. The former starts at an early juvenile stage (geometric diameter $=4.5 \mathrm{~mm}$ ) and continues for the colony's lifetime. However, the latter is seen only in adults (geometric diameter $\geq 31 \mathrm{~mm}$ ). This study showed that the growth rate of $O$. crispata was independent of surface orientation. With the wide range of reproductive and growth strategies available to it, O. crispata is able to colonize a variety of substrata, including those unfavourable for other corals and can, therefore, be regarded as an opportunist coral. Such a life history trait enables it not only to survive in Hong Kong's perturbated shallow marine environment, which other coral species are finding increasingly hard to withstand (Clark 1997, Collinson 1997), but to flourish as a pioneer colonizer of newly immersed structures.

Acknowledgements. I am grateful to Professor B. Morton, Director of The Swire Institute of Marine Science (SWIMS), for his supervision of and comments on the first drafts of the manuscript. I am also indebted to Dr G. Hodgson and the 3 anonymous reviewers for their critical reading of the manuscript. This study was funded by Hong Kong Electric Co. Ltd and China Light and Power Co. Ltd. I would like to thank these companies and various members of their staff for logistical assistance and other support during the course of the research. Thanks also go to the staff of SWIMS, for help with the field work. This work comprises part of the $\mathrm{PhD}$ thesis submitted to The University of Hong Kong.

\section{LITERATURE CITED}

Alino PM, Viva Banzon P, Yap HT, Gomez ED, Morales JT, Bayoneto RP (1985) Recovery and recolonization on a damaged back-reef area at Cangaluyan Island (Northern Philippines). Proc 5th Int Coral Reef Cong Tahiti 4: 279-284

Babcock RC (1985) Growth and mortality in juvenile corals (Goniastrea, Platygyra and Acropora): the first year. Proc 5th Int Coral Reef Cong Tahiti 4:355-360

Bak RPM, Engel MS (1979) Distribution, abundance and survival of juvenile hermatypic corals (Scleractinia) and the importance of life history strategies in the parent coral community. Mar Biol 54:341-352

Bamber RN (1984) The benthos of a marine fly-ash dumping ground. J Mar Biol Assoc UK 64:211-226

Bamber RN (1990) Colonisation and selection of fly-ash substrates by marine invertebrates. Chem Ecol 4:235-246

Bartlett MS (1937) Some examples of statistical methods of research in agriculture and applied biology. J R Stat Soc 4(Suppl):137-170

Berlow EL, Navarrete SA (1997) Spatial and temporal variation in rocky intertidal community organization: lessons from repeating field experiments. J Exp Mar Biol Ecol 214: 249-262

Brown KM (1997) Size specific aspects of the foraging ecology of the southern oyster drill Stramonita haemastoma (Kool 1987). J Exp Mar Biol Ecol 214:249-262

Clark TH (1997) The ecology of indigenous and transplanted corals in the Cape d'Aguilar Marine Reserve, Hong Kong. $\mathrm{PhD}$ thesis, The University of Hong Kong 
Collinson PRJ (1997) The ecology of a peripheral, subtropical coral community in Hong Kong. PhD thesis, The University of Hong Kong

Cope M (1982) Interspecific coral interactions in Hong Kong. Proc 4th Int Coral Reef Symp Manila 2:357-362

Duedall IW, Roethel FJ, Seligman JD (1981) Stabilized power plant scrubber sludge and fly ash in the marine environment. In: Ketchum BH, Kester DR, Park PK (eds) Ocean dumping of industrial wasters. Plenum Press, New York, p 315-346

Fitzhardinge R (1993) The ecology of juvenile Hawaiian corals. PhD dissertation, University of Hawaii, Honolulu

Flynn GB, Scrudato RJ, Gannon JE (1985) Suitability of coalwaste blocks in the freshwater environment of Lake Ontario. In: Duedall IW, Kester DR, Park PK (eds) Wastes in the oceans, Vol 4. Energy waste in the ocean. John Wiley \& Son, New York, p 651-665

Hughes TP (1985) Life histories and population dynamics of early successional corals. Proc 5th Int Coral Reef Cong Tahiti 4:101-106

Humphries EM, Duedall IW, Jordan SJ (1985) Coal-waste blocks as a fouling substrate in estuarine water. In: Duedall IW, Kester DR, Park PK (eds) Wastes in the oceans, Vol 4. Energy waste in the ocean. John Wiley \& Son, New York, p 613-649

Kawaguti S, Sakumoto D (1952) Pigment of skeleton of a reef coral, Oulastrea crispata. Biol J Okayama Univ 1:265-270

Lam KKY (1998) The colonization of an experimental artificial reef at Hoi Ha Wan Marine Park, Hong Kong. PhD thesis, The University of Hong Kong

Leung AWY, Leung KF, Lam KKY, Morton B (1995) The development of an experimental artificial reef in Hong Kong. In: Japan International Marine Science and Technology Federation (ed) ECOSET '95. Proceedings of the International Conference on Ecological System Enhancement Technology for Aquatic Environments. Tokyo, p 131-140

Leung AWY, Leung KF, Lam KKY, Morton B (1997) The evaluation of an experimental artificial reef for the marine habitat rehabilitation and the feasibility of using stabilized coal combustion solid residues for reef construction. Final Report. The Swire Institute of Marine Science, The University of Hong Kong

Loya Y (1976a) Settlement, mortality and recruitment of a Red Sea scleractinian coral population. In: Mackie GO (ed) Coelenterate ecology and behaviour. Plenum Press, New York, p 89-100

Loya Y (1976b) The Red Sea coral Stylophora pistillata is an $r$ strategist. Nature 259:478-480

Loya Y (1985) Seasonal changes in growth rate of a Red Sea coral population. Proc 5th Int Coral Reef Cong Tahiti 6: 187-191

McFadden CS (1986) Laboratory evidence for a size refuge in competitive interactions between the hydroids Hydractinia echinata (Flemming) and Podocoryne carnea (Sars). Biol Bull 171:161-174

Miller KM, Carefoot TH (1990) The role of spatial and size refuges in the interaction between juvenile barnacles and grazing limpets. J Exp Mar Biol Ecol 134:157-174

Nelson WG, Navratil PM, Savercool DM, Vose FE (1988) Short term effects of stabilized oil ash reefs on the marine benthos. Mar Pollut Bull 9:623-627

Neth TE (1991) Comparison of long-term development of fouling communities and benthic infauna between stabilized oil ash and concrete reefs. MSc thesis, Florida Institute of Technology, Melbourne, FL

Nie ZQ, Ji MF, Yan JP (1996) Preliminary studies on increased survival and accelerated growth of overwintering juvenile abalone, Haliotis discus hannai. Aquaculture 140:177-186

Rogers CS, Suchanek TH, Pecora FA (1982) Effects of hurricanes David and Frederic (1979) on shallow Acropora palmata reef communities: St. Croix, U.S. Virgin Islands. Bull Mar Sci 32:532-548

Rogers CS, Fitz HC III, Gilnack M, Beets J, Hardin J (1984) Scleractinian coral recruitment patterns at salt river submarine canyon St. Croix USVI. Coral Reefs 3:69-76

Rosesmyth MC (1984) Growth and survival of sexually produced Acropora recruits: a post-hurricane study at Discovery Bay. Atlantic Reef Commission and International Society of Reef Studies Abstract, Miami, p 105-106

Rylaarsdam KW (1983) Life histories and abundance patterns of colonial corals in Jamaican reefs. Mar Ecol Prog Ser 13: 249-260

Sampaolo A, Relini G (1993) Environmental implications of coal use for artificial reef construction. Proceedings of Tenth International Ash Use Symposium, p 1-11

Sato O (1985) Selected topics on artificial reefs. Coastal Oceanography Research Note 14:88-100 (in Japanese)

Savercool DM (1988) A comparative study of fouling communities on oil ash block and concrete block reefs off Vero Beach, Florida. MS thesis, Florida Institute of Technology, Melbourne, FL

Scott PJB (1984) The corals of Hong Kong. Hong Kong University Press, Hong Kong

Sheppard CRC (1979) Interspecific aggression between reef corals with reference to their distribution. Mar Biol 1: $237-247$

Sokal RR, Rohlf FJ (1995) Biometry. WH Freeman and Co, San Francisco

Van Moorsel GWNM (1985) Disturbance and growth of juvenile corals (Agaricia humilis and Agaricia agaricites, Scleractinia) in natural habitats on the reef of Curaçao. Mar Ecol Prog Ser 24:99-112

Van Moorsel GWNM (1988) Early maximum growth on stony corals (Scleractinia) after settlement on artificial substrata on a Caribbean reef. Mar Ecol Prog Ser 50:127-135

Van Moorsel GWNM (1989) Juvenile ecology and reproductive strategies of reef corals. PhD dissertation, Rijksuniversiteit, Groningen

Vaughan TW (1912) The madreporaria and marine bottom deposits of southern Florida. Carnegie Inst Wash Year Book 10:147-156

Vaughan TW (1915) Reef corals of the Bahamas and of southern Florida. Carnegie Inst Wash Year Book 14:220-231

Veron JEN (1986) Corals of Australia and the Indo-Pacific. University of Hawaii, Honolulu

Wallace CC (1985) Seasonal peaks and annual fluctuations in recruitment of juvenile sclectinian corals. Mar Ecol Prog Ser 21:289-298

Wallace CC, Watt A, Bull GD (1986) Recruitment of juvenile corals onto coral tables preyed upon by Ancanthaster planci. Mar Ecol Prog Ser 32:299-306

Wittenberg M, Hunte W (1992) Effects of eutrophication and sedimentation on juvenile corals. I. Abundance, mortality and community structure. Mar Biol 116:131-138

Woodhead PMJ, Jacobson ME (1985a) Biological colonisation of a coal-waste artificial reef. In: Duedall IW, Kester DR, Park PK (eds) Wastes in the oceans, Vol 4. Energy waste in the ocean. John Wiley \& Son, New York p 585-596

Woodhead PMJ, Jacobson ME (1985b) Epifaunal settlement, the processes of community development and succession over two years on an artificial reef in the New York Bight. Bull Mar Sci 37:364-376

Woodhead PMJ, Parker JH, Duedall IW (1985) The use of 
by-products from coal combustion for artificial reefs. In: D'Itri FM (ed) Artificial reefs: marine and freshwater applications. Lewis Publishers, Chelsea, MI, p 265-292

Yajima T, Osamie S, Okamoto T, Yoshihiro S, Thutomu S, Masahiro M (1986) Ecological distribution of the reef coral, Oulastrea crispata (Lamack) at the shore region in the vicinity of Tsukumo Bay. Bull Jpn Sea Res Inst Kanazawa Univ 18:21-36

Yamaguchi M (1983) Growth data analysis in the reef building

Editorial responsibility: John Austin (Assistant Editor), Oldendorf/Luhe, Germany coral Pocillopora damicornis (Linnaeus). Galaxea 2:21-27 Zar JH (1984) Biostatistical analysis. Prentice-Hall, Inc, Engelwood Cliffs, NJ

Zou RL, Wang ZH, Cheung CPS (1992) A resurvey of the corals at Hoi Ha Wan after eight years and the Tai Long Tun Borrow Area. In: Morton B (ed) Proceedings of the Fourth International Marine Biological Workshop: The marine flora and fauna of Hong Kong and Southern China. Hong Kong University Press, Hong Kong, p 11-29

Submitted: July 5, 1999; Accepted: February 15, 2000 Proofs received from author(s): September 20, 2000 